\title{
Education in the Volga Federal District in the second half of the 19th-20th centuries
}

\author{
Marina Alekseevna Zakharischeva ${ }^{1 *}$, Daria Yuryevna Scriabina $^{1}$, Nadezhda Mikhailovna \\ Ichetovkina $^{1}$, Aleksey Alekseyevich Romanov ${ }^{2}$, and Irina Aleksandrovna Golubeva ${ }^{1}$ \\ ${ }^{1}$ Federal State Budgetary Educational Institution of Higher Education "Glazov State Pedagogical \\ Institute named after V.G. Korolenko", Department of Pedagogy and Psychology, Glazov, Russia \\ ${ }^{2}$ Federal State Budgetary Educational Institution of Higher Education "Academy of Law and \\ Management of the Federal Penitentiary Service of Russia (Academy of the Federal Penitentiary \\ Service of Russia)", Department of Legal Psychology and Pedagogy, Ryazan, Russia
}

\begin{abstract}
The article attempts to present a holistic view of the theory, practice and history of the development of public education in the modern Volga Federal District in the chronological framework of the second half of 19-20th centuries. In order to achieve the presented goal of the research, we used theoretical methods (analysis, synthesis, generalization, modeling, abstraction, classification, systematization, periodization) and historical and pedagogical methods of research, namely, comparison and contrast (comparativist), historical and structural and historical and typological. Within the geographical framework of the Volga Federal District as a complex sociocultural region with the cohabitation and interaction of different nationalities and confessions, the history of education in a holistic form has not been considered before. The authors proposed modern scientific and pedagogical methodological approaches to the analysis of the history of education of the region represented: pedagogical axiology, pedagogical regionalism, pedagogical comparativism, pedagogical synergetic, systemic-activity approaches. For the first time, the theory and practice of public education in the modern Volga Federal District are considered in the context of a unified historical and pedagogical process (without the traditional division into pre-revolutionary and Soviet stages). In addition to theoretical results of the historical and pedagogical research and practical: the formation of a bank of archival materials on the history of education in the republics and regions of the Volga Federal District; publication of the textbook "History of Public Education in the Volga Federal District"; publications in peer-reviewed journals devoted to the study of educational development in the Volga Federal District; organization and conduct of the Pedagogical Festival of Student Science of the Volga Federal District republics; as well as the preparation and production of a series of television programs about the history of the development of public education in the republics and regions of the Volga Federal District.
\end{abstract}

Keywords: historical and pedagogical perspective, pedagogical regionalism, pedagogical axiology, vocational and inclusive education

\footnotetext{
*Corresponding author: zahari-ma@rambler.ru
} 


\section{Introduction}

As a state structure, the Volga Federal District (VFD) is a complex multi-level socioeconomic, cultural, scientific and pedagogical community with a rich history and traditions of peaceful coexistence of different peoples. This potential has not been sufficiently explored through the theory and history of pedagogy and represents a vast resource for historical and pedagogical justification of the values of contemporary justification.

The purpose of our research is to present in a holistic form the theory, practice and history of the development of public education in the modern VFD (second half of the $19^{\text {th }}$ 20th centuries).

Among the objectives of the study, we defined the methodological foundations of the study, namely, pedagogical axiology, pedagogical regionalism, pedagogical comparativism, pedagogical synergetics, systems-activity approach. Clarification of the conceptual and terminological field of research is the next task. In addition, based on the analysis of the sources, it is possible to identify the leading trends in the development of the theory and practice of public education within the modern VFD (second half of the $19^{\text {th }}-20$ th centuries), which will identify the leading factors in the development of the theory and practice of public education within the modern VFD during the period under consideration.

With a historical and comparative method, the internal periodization of the process of development of education in VFD in the period under review is substantiated and the general and special at each stage is characterized. Justify the constructive ideas and conclusions of the development of public education in the modern VFD in the period under review as relevant and promising at the present stage allows an axiological approach to the study.

\section{Methods}

The study used a set of scientific methods. Theoretical methods include analysis, synthesis, generalization, modeling, abstraction, classification, systematization, periodization. In addition, special historical and pedagogical methods are represented by a comparative (comparativist) method, which allows scientific analysis of the process of development of public education in different subjects of the VFD. Historical and structural method involves identifying systemic components in the theory and practice of public education in the system of general, vocational and inclusive education in the VFD in the period under review. Using the historical and typological method, methodological approaches to the problem of research are highlighted, the conceptual field is defined, trends are identified and constructive conclusions are formulated, significant for the modern school in the individual subjects and the VFD as a whole.

The scientific approaches of the study are represented by axiological, regionalist, comparativist, synergetic and systemic-activity approaches.

The axiological approach acts as a kind of "bridge" between the theory and practice of organization and development of education in the regions of the VFD [1-3]. The perspective of the axiological approach is disclosed in a holistic view of the theory, practice and history of the development of public education in the modern VFD.

The regional-analytical approach allows us to analyze and highlight the common and special in different subjects, as well as in the VFD as a region of Russia as a whole.

Pedagogical comparativism, that is, comparative analysis sets the phenomena and parameters of comparison, which helps to identify the main stages and trends of development both in the region (VFD) as a whole, and in each individual subject in particular. 
Pedagogical synergetics meets modern scientific ideas about the trajectory of educational development in different periods under the influence of a complex of factors (political, economic, social, cultural, scientific, national, confessional, psychological and pedagogical). The system-activity approach involves consideration of the problems of theory and practice of education at different levels: preschool, general secondary education; primary, secondary and higher professional levels of education.

\section{Results and discussion}

For the first time, the history of education is considered in the geographical framework of the VFD as a complex socio-cultural region with the cohabitation and interaction of different nationalities and religions. For the first time, the history of education of the region is considered on the basis of the following methodological approaches: pedagogical axiology, pedagogical regionalism, pedagogical comparativism, pedagogical synergetics, systematic-activity approach. For the first time, the theory and practice of public education in the modern VFD are considered in the context of a unified historical and pedagogical process (without division into pre-revolutionary and Soviet stages).

The research problem is to find an answer to the question: How have contradictions been resolved in the course of historical development

- between a single governing center and the preservation of regional traditions of education;

- between the influence of different national cultures and world religions on education;

- between personnel support from the center and the need to nurture and educate national elites in the regions?

Historical and pedagogical periodization allows us to offer different solutions to the above contradictions, which leads to the formation of models for the development of education in the VFD during the period under review.

Analysis of the current state of research in this area. At present, the formation of pedagogical regionalism as a direction of pedagogical thought [4] is taking place in science. The leading scientists in this field are Volkov [5] and Pomelov [6]. The next group of sources can be called fundamental research on the history of education development in a particular subject of the VFD of the Russian Federation: Aminov (Republic of Bashkortostan) [7, 8]; Ivanov [9] and Komelina (Republic of Mari-El) [10], Shukshina (Republic of Mordovia) [11], etc. Comparative and comparative studies are conducted to identify the common and special in the development of education in the region [12-22]. At the same time, the history of education in the VFD has not received detailed and holistic attention from historical and pedagogical science and has not been characterized as a complex multidimensional cultural and pedagogical phenomenon.

Expected results of the project and their significance. In addition to the theoretical results of the historical and pedagogical research, it is planned to obtain practical ones: forming a bank of archive materials on the history of education in the republics and regions of the VFD; publication of the textbook "History of Public Education in the VFD"; publications in peer-reviewed journals devoted to the study of the development of education in the VFD; organizing and conducting a pedagogical festival of student science in the VFD republics; and preparing and producing a series of television programs on the history of the development of public education in the republics and regions of the VFD.

\section{Conclusion}


The main conclusions of the study should include: clarification of the main categories of research, taking into account the specifics of the development of public education in individual regions and the VFD as a whole. The paper proposes an internal periodization of the process of development of public education without the traditional division into prerevolutionary and Soviet periods. The models and trends in the development of public education in the VFD are distinguished and characterized.

\section{References}

1. N.P. Khvataeva, et al., Asia Life Sci. Suppl. 1(1), 1-6 (2020)

2. N.P. Khvatayeva, Espacious, 39(20), 9 (2018)

3. N.P. Khvatayeva, Mod. Hum. Success, 6, 223-228 (2020)

4. V.B. Pomelov, Istoriko-pedagogicheskaya regionolistika [Historical and pedagogical regionalism] (Vyatka State University, Kirov, 2020)

5. G.N. Volkov, Etnopedagogika [Ethnopedagogy] (Academia, Moscow, 2000)

6. V.B. Pomelov, Prosveshchenie nerusskikh narodov Vyatskogo kraya (XIX - nachalo XX vv.), Prosveshchenie v Vyatskom krae (XIV - nachalo XX v.) [The Education of Non-Russian Peoples of the Vyatka Region (19th -beginning of the 20th century), The Education in the Vyatka Region (14th - beginning of the 20th century)] (Vyatka State University, Kirov, 2019)

7. T.M. Aminov, Istoriya professionalnogo obrazovaniya v Bashkirii. Nachalo XVII veka - do 1917 goda [History of professional education in Bashkiria. The beginning of the 17th century up to 1917] (Nauka, Moscow, 2006)

8. T.M. Aminov, R.M. Khusainov, Razvitie kommercheskogo obrazovaniya v Bashkirii (1908 - 1967): ot Torgovoi shkoly do Ufimskogo professionalnogo torgovogo uchilishcha [The Development of Commercial Education in Bashkiria (1908-1967): from the Trade School to the Ufa Professional Trade School] (Publishing house Gilem, Ufa, 2009)

9. A.G. Ivanov, Razvitie regiona Mariiskogo Povolzhya v sostave Rossiiskogo gosudarstva vo vtoroi polovine XVI-XVII vv. [Development of the Mari Volga region as part of the Russian state in the second half of the XVI-XVII centuries], in A. Kappeler (ed.), Die Geschichte Russlands in 16. und 17. Jahrhundert aus der Perspektive Seiner Regionen, 342-362 (Harrassowitz Verlag, Berlin, 2004)

10. V.A. Komelina, et al., Razvitie professionalno-tekhnicheskogo obrazovaniya $\mathrm{V}$ Mariiskoi ASSR v poslednei treti XX veka [The Development of Vocational Education in the Mari Autonomous Soviet Socialist Republic in the Last Third of the XX Century] (MarSU, Ioshkar-Ola, 2011)

11. T.I. Shukshina, et al., Hum. Edu.: Sci.-Method. J. 4(28), 8-14 (2016)

12. I.A. Golubeva, Bul. Kostroma State Univ., Ser.: Pedag. Psy. Sociokinetics 26(4), 216222 (2020). https://doi.org/10.34216/2073-1426-2020- 26-4-216-222

13. I.A. Golubeva, Osnovnye etapy razvitiya nauchno-issledovatelskoi deyatelnosti studentov v pedagogicheskikh vuzakh PFO v 50-80 gg. XX veka [The main stages of development of students' research activities in pedagogical universities of the Volga Federal District in the 50-80s. of the 20th century], in Materials of the International Scientific and Practical Conference. XXXIII Session of the Scientific Council on the History of Education and Pedagogy at the Department of Philosophy of Education and Theoretical Pedagogy of the Russian Academy of Education, June 9-10 St. Petersburg, 417-421 (2020) 
14. E.S. Guzenko, Blagotvoritelnost v sisteme obrazovaniya kontsa XIX - nachala XX veka: Na materialakh Kazanskoi, Simbirskoi i Saratovskoi gubernii [Charity in the system of education in the late 19th - early 20th century: On the materials of Kazan, Simbirsk and Saratov provinces]. Abstract of a PhD thesis in History (Saratov State Social-Economic University, Saratov, 2001)

15. E.I. Demydova, Formirovanie sovetskoi sistemy vysshego obrazovaniya [Formation of the Soviet system of higher education] (SSSEU, Saratov, 2007)

16. M.A. Zakharishcheva, Stanovlenie pedagogicheskogo obrazovaniya v Udmurtskoi Respublike pervoi treti XX stoletiya [Formation of pedagogical education in the Udmurt Republic in the first third of the 20th century], in Teacher and his formation: Historical Experience of Transmission of Education and Culture: Collection of Scientific Works of the International Scientific-Practical Conference. XXXI Session of the Scientific Council on the History of Education and Pedagogy of the Russian Academy of Education, June 6-7, Tver, 428-435 (2016)

17. M.A. Zakharishcheva, Rus.-Chin. Sci. J. "Sodruzhestvo" 22, 22-25 (2018)

18. M.A. Zakharishcheva, East. Europ. Sci. J. 4, 71-82 (2019)

19. N.M. Ichetovkina, Klassnoe nastavnichestvo v vospitatelnoi sisteme otechestvennoi gimnazii vo vtoroi polovine XIX-nachale XX vv. (na materiale Kazanskogo uchebnogo okruga) [Class counseling in the educational system of the domestic gymnasium in the second half of the 19th and early 20th centuries. (on the material of the Kazan school district)] (Publishing house "Buk", Kazan, 2017)

20. N.M. Ichetovkina, et al., Transformatsiya sistemy vospitatelnoi deyatelnosti klassnogo rukovoditelya: istoriko-pedagogicheskii aspekt [Transformation of the system of educational activities of the class teacher: historical and pedagogical aspect], in Preparation of the professional of the XXI century: Theoretical searches and effective practices (OANO VO “MPSU”, RIO BSU, Moscow - Bryansk, 2020)

21. N.M. Ichetovkina, Sci. Notes V.I. Vernadsky Crimean Fed. Univ. Soc. Pedag. Psy. 1(6), 25-36 (2020)

22. D.Yu. Skryabina, Mod. Human. Success, 3, 41-49 (2021)

23. D.Yu. Skryabina, V.V. Bazhenova, Sci. and Sch. 1, 68-78 (2020) 